\title{
Mandatory Disclosure about Environmental and Employee Matters in the Reports of Italian-Listed Corporate Groups
}

\section{Ericka Costa \& Marisa Agostini}

To cite this article: Ericka Costa \& Marisa Agostini (2016): Mandatory Disclosure about Environmental and Employee Matters in the Reports of Italian-Listed Corporate Groups, Social and Environmental Accountability Journal

To link to this article: http://dx.doi.org/10.1080/0969160X.2016.1144519

曲 Published online: 15 Mar 2016.

Submit your article to this journal $₫$

a)

View related articles $\sqsubset$

View Crossmark data $\nearrow$ 


\title{
Mandatory Disclosure about Environmental and Employee Matters in the Reports of Italian-Listed Corporate Groups
}

\author{
Ericka Costa ${ }^{a}$ and Marisa Agostini ${ }^{b}$ \\ ${ }^{a}$ Department of Economics and Management, University of Trento, Via Inama 5, Trento 38100, Italy; \\ ${ }^{b}$ Department of Management, Ca' Foscari University of Venice, San Giobbe Cannaregio 873, Venice 30121, \\ Italy
}

\begin{abstract}
This paper analyses the impact of Italian Legislative Decree 32/2007 - following the 2003/51 European Directive - and the disclosure of environmental and employee matters in terms of overall volume, completeness of information, presence of $\mathrm{bad} / \mathrm{good}$ news and target-oriented information. Content analysis has been applied to all Italian corporate groups that made public both the consolidated annual report and the stand-alone social and environmental report in 2005 and in 2010, for a total of 96 reports. The results show that despite the overall increase in sentences devoted to environmental and employee matters, the completeness of the information has not substantially improved, indicating that the 2007 regulation has been ineffective. The Italian experience could provide useful insights for European regulators. Such insights may inform policy recommendations to design a mandated social and environmental accountability process with the potential of providing information to societal stakeholders while facilitating accountability.
\end{abstract}

\section{Introduction}

Recently, the European Commission has begun facing the urgent challenge of regulating social and environmental matters for large companies and groups (European Directive 2014/95/EU of 15 November 2014). The regulation seeks to improve the transparency of European companies by compelling them to disclose information on policies, risks and outcomes regarding environmental matters as well as social and employee-related aspects. This regulation is intended to be flexible, allowing companies to provide integrated information in the annual and stand-alone reports while adopting the European or national guidelines they consider most appropriate.

This legislative process began in 2003 with the release of Directive 2003/51/EC regarding non-financial disclosures in companies' annual reports and consolidated annual reports. Prior to 2003, the European Commission encouraged organisations to disclose information beyond 'the financial aspects of the company's business'. As such, the Commission expected that a company's development, performance and position could be viewed through the lens of environmental and social aspects (article 9, 2003/51/EC).

CONTACT Ericka Costa $\otimes$ ericka.costa@unitn.it

(c) 2016 Centre for Social and Environmental Accounting Research 
Some European countries (Spain, France, Portugal, Finland, Sweden and Denmark) have adopted this European recommendation by obliging companies to deliver information about social and environmental matters in their annual reports.

In this regard, Italy adopted the 2003/51/EC European Directive with Legislative Decree 32/2007 (D.Lgs. 32/2007, hereafter). This 2007 legislation represents the first Italian decree to recommend the provision of employee and environmental information through consolidated annual reports. The inclusion of this information recognises the increasing importance of social and environmental accounting (SEA) and non-financial information (i.e. environmental, social and governance issues), both of which may represent a significant portion of corporate value.

It is helpful to analyse Italy's implementation of 2003/51/EC in order to uncover possible successful approaches for future application of the most recent 2014/95/EU regulation. Indeed, the two regulations are similar in scope - to promote and enhance companies' disclosure of social and environmental information - but quite different in focus and application. The 2003/51/EC regulation and the related Italian D.Lgs. 32/2007 were quite broad and unfocused, failing to explicitly consider the role of stand-alone social and environmental reports; the recent 2014/95/EU better defines social and environmental issues and considers the possibility of omitting these issues from the consolidated annual report when a stand-alone social and environmental report is present. Because of the differences between the 2003 and 2014 EU regulation, this paper considers the 2007 Italian regulation as a case that promotes a better understanding of the potentiality of the more recent $2014 \mathrm{EU}$ regulation. It does so by analysing aspects that have not functioned properly in Italy within the 2007 regulation; it also investigates how the recent 2014 EU regulation can be considered a step forward in promoting the disclosure of non-financial information in order to measure, monitor and manage companies' performance and impacts on global society.

Several studies in the SEA literature have investigated the role of social and environmental mandatory disclosure (Larrinaga et al. 2002; Mobus 2005) and voluntary disclosure (Kolk 2005; KPMG 2011). Such studies have attempted to understand if regulation can ameliorate the lack of neutrality and objectivity characterising voluntary disclosure (Adams 2004; Deegan and Rankin 1996; Gray 2006). The debate about voluntary and mandatory disclosure and the role of regulation in SEA remains necessary and timely (Jeffrey and Perkins 2013; Parker 2014). Indeed, on one hand, many scholars have affirmed that compulsory social and environmental disclosure is the most appropriate approach (Bebbington and Thy 1999; Hibbitt and Collison 2004; Jeffrey and Perkins 2013; Owen, Gray, and Bebbington 1997). Meanwhile, several other studies have demonstrated that many companies fail to comply with the standard or law despite mandatory disclosure (Adams, Coutts, and Harte 1995; Criado-Jiménez et al. 2008; Day and Woodward 2004; Larrinaga et al. 2002; Llena, Moneva, and Hernandez 2007). When they do comply, the quality of the social and environmental disclosure tends to be fairly low.

Despite the increasing number of contributions to this topic, most of the research focuses on the reports' legal compliance (Criado-Jiménez et al. 2008; Larrinaga et al. 2002). Such efforts fail to consider companies' overall disclosures on social and environmental issues. They also lack analysis of the disclosures' nuances, such as completeness in terms of descriptive/quantitative information, bad/good news and past/target-oriented issues. Moreover, most researchers consider the annual report to be the most important 
document, leading to a dearth of investigations that consider annual reports and standalone social and environmental reports together (Adams, Coutts, and Harte 1995; Gray, Kouhy, and Lavers 1995).

In order to contribute to this academic debate, this paper has a twofold purpose: first, it aims to empirically verify if and how the information about environmental and employee matters has changed from 2005 to 2010, both in annual reports and in social reports; this analysis includes overall volume, completeness of information, presence of bad/good news and target-oriented information. Second, the paper investigates the extent to which Italian D.Lgs. 32/2007 explains the variability of the provided environmental and employee information.

From a methodological point of view, this paper uses a regression model to develop a content analysis (Krippendorf 1980) of 96 reports (24 consolidated annual reports and 24 stand-alone social and environmental reports) in 2005 and 2010. The results show that despite the overall increase in sentences devoted to environmental and employee matters, the completeness of the information has not substantially improved, indicating that the 2007 regulation has been ineffective.

The paper is organised as follows. The next section introduces the EU regulations from 2003 to 2014 and their implementation in Italy. Then, the literature review presents information regarding SEA studies and the voluntary/mandatory disclosure debate. The fourth section presents the hypotheses for this research. The fifth section describes the sample of Italian-listed companies and introduces the content analysis performed on the consolidated annual reports and stand-alone social and environmental reports. Section six illustrates the empirical evidence and discusses the findings. The paper concludes with final remarks and policy implications.

\section{The EU Regulations from 2003 to 2014 and Their Implementation in Italy}

The most important European initiative regarding accounting for environmental issues dates back to 1992 when the European Commission published the programme, 'Towards Sustainability' (2001/453/EC). This programme primarily discussed how companies report on financial aspects relating to the environment and recognised that traditional financial reporting should include more about corporate performance. Additional information would increase the reliability of accounting and financial data, making it more valuable for assessing firm value and management performance.

After this initiative, in May 2001, the European Commission provided recommendations regarding the recognition, measurement and disclosure of environmental issues in companies' annual reports. The document clearly recognised two major issues: first, different stakeholders - regulatory authorities, investors, financial analysts and the general public may consider the environmental information disclosed by companies to be inadequate or unreliable because of the lack of explicit rules and standards. Second, by adopting standalone environmental reports, firms in most European countries are expanding both the quantity and the quality of their environment-based information disclosures (KPMG 2011).

Therefore, the European Commission encouraged stand-alone environmental reports and annual reports to be more consistent, cohesive and closely associated. In light of this development, the European Commission's Recommendation 2001/453/EC of 30 May 2001 ensured that 'environmental disclosures are incorporated in the annual 
accounts and annual reports in a way that complements the more detailed and wideranging separate environmental reports' (2).

This approach confirms the progressive International Financial Reporting Standard inability (especially pertaining to IAS 1, 8, 32 and 39) to reflect corporate responsibility measures in financial accounts and the urgent need for regulatory authorities to recognise the impossibility of continuing to rely on separate reports without knowing how environmental disclosures affect companies' overall performance.

In 2003, the European Commission launched Directive 2003/51/EC that, consistent with the Commission Recommendation 2001/453/EC of 30 May 2001, promotes a 'fair review' of financial, social and environmental aspects of companies, aspects necessary for understanding any company's development, performance or position. In detail, the European Directive 2005/51/EC introduced many new features regarding the drawing up of business reports, including the point of view of non-financial indicators:

both financial and, where appropriate, non-financial key performance indicators relevant to the particular business, including information relating to environmental and employee matters must be included in the consolidated annual reports in order to enable a balanced and comprehensive analysis of the development and performance of the business. (Directive 2003/51/EC, 4)

The European Directive 2003/51/EC was introduced in Italy with Legislative Decree 2 February 2007, n.32 (D.Lgs. 32/2007, hereafter). This decree was a first step in satisfying the need for disclosures regarding non-financial performance indicators. In detail, this Italian legislative decree obliges consolidated annual reports to include information regarding environmental and employee matters. However, it does not add any specific instructions regarding how to interpret the concept of 'environment' and 'employee'. Many questions have therefore remained open and unsolved: which kind of information about environmental and employee matters must be disclosed? How much detail is required? The Italian regulation does not provide any additional information to better guide companies in more broadly disclosing non-financial information within consolidated annual reports. In addition, professional accountants have discussed how to interpret the Italian regulation, and they referred to the previous European Recommendation 2001/453/EC of 30 May 2001, suggesting 'an analysis of the environmental and social aspects necessary to understand the development, performance or position of a company' (Sirimarco 2007, 50). They also make reference to other kinds of reporting, such as stand-alone social and environmental reporting, which are specifically designed to provide more effective information to various stakeholders.

Italy's application of European Directive 2003/51/EC to non-financial information regarding environmental and employee matters has remained ambiguous because of the broad and vague nature of the law. Adding to this ambiguity is the inability of accounting professionals to better detail the directive's content. While D.Lgs. 32/2007 represents the first Italian regulation to recommend the provision of employee and environmental information within consolidated annual reports, the European Commission has advanced measures to improve the transparency of the social and environmental information provided by companies in all sectors. With Directive 2013/0110, the European Parliament and the Council presented a proposal regarding the disclosure of non-financial and diversity information for certain large companies and groups. 
After a long process of consultation with other stakeholders, they recognised that 'only a limited number of EU large companies regularly disclose non-financial information, and the quality of the information disclosed varies largely, making it difficult for investors and stakeholders to understand and compare companies' position and performance' (European Commission 2013/0110, 2). In essence, they propose requiring certain large companies to disclose relevant non-financial information in order to allow investors to better evaluate sustainability and long-term performance across companies in Europe.

This proposal would also maintain a flexible and non-intrusive approach in order to allow companies to adopt their preferred national or international reporting frameworks. The proposal further intends to solve the problem of fragmentation in legislative frameworks across Europe by allowing European countries to privilege different methods of disclosure and to require certain kinds of companies to provide such information (Firoz and Ansari 2010).

On 15 November 2014, the European Parliament recognised the importance of businesses disclosing information on social and environmental matters and approved Directive 2014/95/EU regarding disclosure of non-financial and diversity information by certain large undertakings and groups.

Compared to Directive 2003/51/EC, Directive 2014/95/EU is clearer, focusing on enhancing the consistency and comparability of social and environmental information throughout EU companies in order to reduce fragmentation. Therefore, 2014/95/EU better describes the kinds of social and environmental matters that have to be detailed (i.e. gender equality, working conditions, social dialogue, respect for worker's rights, respect for trade union rights, health and safety at work, land use, water use and greenhouse gas emissions). It also leaves room for member states to exempt organisations that have a stand-alone social and environmental report that covers the same topics, in essence providing a specific non-financial report.

Italy has not yet adopted this recent EU directive, which differs in two primary ways from the previous 2003/51/EC. First, Directive 2014/95/EU exemplifies a set of social and environmental items that should be included within the non-financial disclosure, therefore providing companies a clear guide for discharging accountability. Second, it explicitly recognises the remarkable development of stand-alone social and environmental reports in EU member states, therefore allowing national governments the freedom to provide some exemptions on the basis of their national contexts.

To date, Italy has not adopted this recent directive 2014/95/EU; Italian companies have to comply with the previous 2003/51/EC. Therefore, D.Lgs. 32/2007 represents the first Italian regulation to promote the presence of extra-financial information in the consolidated reports of corporate groups (Sirimarco 2007).

\section{Empirical Research on Regulated Social and Environmental Matters}

Information with regard to social and environmental matters can be voluntary or mandatory. By definition, 'voluntary [... ] disclosures, primarily in annual reports, are a communication mechanism by which firms attempt to satisfy external pressures to conform to socially acceptable norms, perhaps substituting this communication mechanism for any substantive behavioural performance' (Mobus 2005, 495). By comparison, mandatory disclosures occur when firms comply with the requirements established by law. 
Scholars in accounting agree that voluntary disclosure is characterised by a lack of completeness, accuracy, neutrality and objectivity because it depends upon the managers' intentions (Adams 2004; Beets and Souther 1999). Beets and Souther (1999) further criticise voluntary disclosure by arguing that it differs significantly from company to company, thereby confounding comparability. Researchers also question the credibility of these reports because they are not always verified by independent third parties.

With regard to social and environmental matters, there is evidence that voluntary social and environmental information fails to enhance disclosures, presenting a high degree of incompleteness (Adams 2004). Scholars have thus suggested that the discharge of accountability requires regulation (Bebbington and Thy 1999; Jeffrey and Perkins 2013; Owen, Gray, and Bebbington 1997). Accepting this perspective, numerous countries have introduced such regulations for SEA in consolidated annual and/or stand-alone social and environmental reports. More specifically, some European countries, such as Spain, France, Portugal, Finland, Sweden and Denmark (see Hibbitt and Collison 2004), have modified their accounting regulations to align with the European Recommendation (2001/453/EC), introducing an obligation for companies to report on environmental matters in their annual reports.

In the Spanish case, Criado-Jiménez et al. (2008) followed up on Larrinaga et al. (2002), investigating the introduction of the 2002 ICAC (Instituto de Contabilidad y Auditoria de Cuentas, Accounting and Auditing Institute) standard that obliged organisations to make environmental disclosures in their financial statements. Criado-Jiménez et al. (2008) indicate that the volume and quality of disclosure increased (especially relating to bad news) despite a considerable level of non-compliance (approximately 84\%). Similarly, Llena, Moneva, and Hernandez (2007) note a considerable increase in environmental disclosure in 51 Spanish firms investigated between 1992-1994 and 2001-2002, but the degree of compliance remained heterogeneous, and the information reported (especially in 2001-2002) was generic and positively biased.

In the UK, Adams, Coutts, and Harte (1995) found that 11 out of 100 listed companies failed to report on equal opportunity; the general level of disclosure was also very low. Day and Woodward (2004) demonstrated that only 58\% of 100 large UK London Stock Exchange-listed companies furnished details according to the 1985 Company Act. This study exposes a high degree of non-compliance with the statutory requirements and raises questions about the symbolic rather than substantive intent of making organisations accountable.

Bebbington and Thy (1999) demonstrate that $83 \%$ of Danish companies have a high degree of compliance with the law, thus noting the positive outcomes of the mandatory Danish Environmental Protection Act; however, the remaining literature shows disappointing results when evaluating the compulsory regulation of social and environmental matters. Therefore, more work is required to evaluate and understand the effectiveness of social and environmental regulation in terms of the volume and 'quality' of reporting (Bebbington and Thy 1999). Such research should pay particular attention to various countries and reporting media (Criado-Jiménez et al. 2008).

\section{Hypotheses Development}

In the light of the aforementioned studies, we intend to investigate the effects of the Italian regulation on mandatory disclosure in consolidated annual reports and to verify 
if such variations correspond to stand-alone social and environmental reports. Therefore, our first hypothesis states the following:

$\mathrm{H} 1$ : After the 2007 regulation, the volume of disclosures about environmental and employee matters will increase.

For the purpose of this study, the analysis of the overall extent of disclosure is insufficient because volume-based evaluation may be misleading (Toms 2002; Unerman 2000). Thus, we also aim to investigate the extent to which the introduction of such regulation on environmental and employee matters enhances the completeness of the reported information in terms of the presence of descriptive or numerical information, the presence of good/bad news and the presence of target-oriented information.

\subsection{Narrative vs. Quantitative Information}

Following Guthrie and Parker (1990), we intend for this hypothesis to investigate the dominance of either narrative or quantitative disclosure. We agree with Al-Tuwaijri, Christensen, and Hughes (2004) who assert that 'quantitative disclosures are more objective and informative to stakeholders than qualitative information' (454). We consider numerical information more complete than simple descriptive and narrative details. However, several studies demonstrate that reports usually contain more narrative and descriptive disclosure than quantitative/numerical information.

Robertson and Nicholson (1996) show that fund managers and analysts perceive quantified environmental information to be more important than non-quantified information. The analysis clearly demonstrates that numerical information adds value to environmental disclosures. Previous studies, however, highlight the ubiquitous presence of narrative information. Kolk (2005) points out that 'there is a clear move towards reporting on the societal aspects, but so far, this has implied more the expression of concerns, intention and policies than the actual measurement of corporate behaviour and/or impacts' (288). In other words, little numerical information is provided, leading to more narrative and descriptive disclosures.

Because introducing regulation should enhance the quality of disclosure and reduce manipulative intentions (Mobus 2005), we expect Italian companies to reduce mentioned statements and increase descriptive and numerical information following Italian Legislative Decree 32/2007.

$\mathrm{H} 2$ : After the 2007 regulation, there will be a significant decrease of mention statements in favour of a significant increase in the amount of numerical information.

\subsection{Bad and Good News}

Confirming that firms tend to be self-laudatory in their disclosure practices, studies on environmental disclosures reveal that information unfavourable to a company's image goes underreported or remains completely absent in corporate reports (Deegan and Gordon 1996; Guthrie and Parker 1990). Guthrie and Parker (1990) provide evidence that the majority of bad news disclosures for US companies was prompted by private regulation in the form of professional accounting standards (FASB) and audit standards (AICPA). 
Deegan and Rankin (1996) have demonstrated how private sector organisations in Australia fail to report 'bad news'; indeed, 'organizations appear reluctant to provide any information within their annual reports about any negative environmental implications of their operations' (59). They conclude that 'annual reports that omit particular environmental information, or provide it in a biased manner, are misleading in that they do not provide a full picture of the operations of the business for the period under review' (62).

Deegan and Gordon (1996) note that, in the absence of regulation, companies are less objective in their disclosures practices and tend to provide information that is favourable to their corporate image. In theory, regulation should reduce the opacity of bad news regarding environmental and employee matters (Larrinaga et al. 2002, 724); however, the introduction of such regulations in Spain did not lead companies to report more bad news (733).

Because Italian Legislative Decree 32/2007 does not specify the information that has to be reported with regard to employee and environmental matters, it enables various forms of disclosures. Therefore, from 2005 to 2010, we expect there to be no significant differences in terms of bad news information disclosed both in consolidated annual reports and stand-alone social and environmental reports.

H3: After the 2007 regulation, there will be a significant increase (decrease) in bad (good) news reported.

\subsection{Target-oriented Information}

Finally, as suggested by Hasseldine, Salama, and Toms (2005), the measurement of social and environmental disclosure should also include the use of target references to outcomes. The authors adapted Toms (2002) model and developed a five-point scale that attributes a higher score when future quantified information is defined (but not published) or when sentences refer to the implementation of targets and quantified results (published). According to Hasseldine, Salama, and Toms (2005), companies that disclose environmental information also consider target references and provide numerical information, thus receiving a higher score than other companies.

In this sense, the presence of target-oriented information as well as information about past events could reveal if companies are employing the stand-alone social report and the financial-consolidated report not only as a form of performance monitoring, but also as a strategic tool for organisational planning (Riccaboni and Leone 2010). As argued by Bebbington $(2007,6)$, 'If organizations are seeking to report on their contribution to sustainable development, one may expect that there are some internal mechanisms which guide their activities toward this goal.'

On the basis of these premises, the fourth hypothesis has been developed as follows:

H4: After the 2007 regulation, there will be a significant increase of target-oriented information and past information about environmental and employee matters.

\section{Research Design}

\subsection{Sample}

According to the Italian D.Lgs. 32/2007, from 1 January 2008, the consolidated annual reports of corporate groups must include information regarding environmental and 
employee matters; however, the Italian law fails to provide any details regarding the kind of information that has to be reported (Sirimarco 2007). Professional accountants therefore suggest consideration of other reports, such as the stand-alone social and environmental report. The sample used in this paper thus consists of Italian corporate groups that provided the consolidated annual report and the stand-alone social and environmental reports both in 2005 (before the 2007 regulation) and in 2010 (after the 2007 regulation) (see Table 1 for a better description of the different names/labels for these reports).

In order to identify the Italian-listed corporate groups, we analysed the CONSOB website. CONSOB is the National Commission for Companies and Stock Markets (Commissione Nazionale per le Società e la Borsa), the public authority responsible for regulating the Italian securities market. In October 2011, there were 264 listed corporate groups in Italy, and 24 of them had both a consolidated annual report and a stand-alone social and environmental report both in 2005 and in 2010, for a total of 96 reports.

We decided to focus on 2005 and 2010 reports - instead of developing a longitudinal content analysis from 2005 to 2010 - for many reasons. First, since the law was introduced on 1 January 2008, we analysed the two years before and after its introduction. Second, in the data from 2005 to 2010, some companies may not have delivered every year's standalone social and environmental report. Third, the analysis of the 96 reports included in this paper has been carried out manually, and although labour-intensive and time-consuming, it allows researchers to conduct a more thorough and in-depth analysis (Brennan, Guillamon-Saorin, and Pierce 2009). Finally, other researchers had focused on social and environmental matters in Italy in 2005 (Andreaus 2007; Pesci and Andrei 2011), thus providing a basis for comparison and trend analysis.

\subsection{Content Analysis}

Content analysis enables the researcher to collect large amounts of textual information and systematically identify its properties (Krippendorf 1980). From a methodological viewpoint, many studies in both financial accounting and environmental-social disclosures adopt an analytic content approach (see Parker 2014). For the purpose of this study, we performed an extent-based content analysis. Focusing on the amount of information, we aimed 'to quantify the extent of reporting on a specific issue using various measures such as words, sentences or pages' (Hooks and Van Staden 2011, 200).

The debate regarding the most appropriate unit of measurement remains open (Hooks and Van Staden 2011; Pesci and Costa 2014; Unerman 2000). Unerman (2000) notes a number of possibilities when quantifying a text: (i) the number of documents containing a particular category of disclosure; (ii) the number of characters; (iii) the number of words; (iv) the number of sentences; ( $v$ ) the number or proportion of pages and (vi) the proportion of volume. Some scholars consider words to be the most appropriate units of measurement because more detail can be achieved using this measure (Deegan and Gordon 1996; Zeghal and Ahmed 1990). Other scholars (Hooks and Van Staden 2011; Milne and Adler 1999) prefer sentences both as a unit of coding and as a unit of measurement because it diminishes the number of problems associated with reliability. However, when adopting sentences, the analysis does not consider different grammatical choices, thus disregarding the length of each sentence (Hooks and Van Staden 2011). In order to resolve this issue, Beattie and Thompson (2007) propose the use of text units for 
Table 1. The sample

\section{Acegas}

Acea

Autogrill
Banca Pop

Banca Carige

Banca Credito Valtellinese

Banca Monte Paschi Siena

Banca Nazionale Lavoro

Banca Popolare Etruria

Buzzi Unicem

Cattolica Assicurazioni

Edison

Enel

Fondiaria - Sai

Hera

Indesit company

Italcementi

Pirelli

Sabaf

Telecom

Unicredit

Unipol gruppo finanziario

IREN (Aem Torino 2005)

Total number of pages
Public utilities

Travel and leisure

Banking

Banking

Banking

Banking

Banking

Banking

Construction

Insurance

Energy

Energy

Automotive

Insurance

Public utilities

Products to people

Public utilities

Automotive

Tecnology

Telecommunications

Banking

Banking

Public Utilities
Stand-alone social and environmental report

$$
\text { (2005) }
$$

Bilancio Integrato

Bilancio di Sostenibilità

Rapporto di Sostenibilità

Bilancio Sociale

Bilancio Sociale

Bilancio Sociale

Bilancio Socio-Ambientale

Bilancio della responsabilità sociale

Bilancio Sociale

Bilancio di Sostenibilità

Bilancio Sociale

Rapporto sulla Sostenibilità

Bilancio di Sostenibilità

Rapporto di Sostenibilità

Rendiconto Sociale

Bilancio di Sostenibilità

Rapporto sulla Sostenibilità

Sustainable Development Report

Bilancio di Sostenibilità (estratto BI)

Bilancio Integrato

Bilancio di Sostenibilità (estratto $\mathrm{BI}$ )

Bilancio Sociale Ambientale

Bilancio Sociale di Gruppo

Bilancio di Sostenibilità
Consolidated

annual report

Stand-alone social and environmental report (2010) (n. of pages)

No. pages

$229 \quad 135 \quad 56$

Bilancio di Sostenibilità

Raporto di Sostenibilità

Bilancio Sociale

Bilancio Sociale

Rapporto Socic

La Responsabiltà Sociale del Gruppo

Bilancio Sociale

Bilancio Sociale

Bilancio di Sostenibilità

Bilancio Sociale

Rapporto di Sostenibilità

Bilancio di Sostenibilità

Bilancio di Sostenibilità

Rendiconto Sociale

Bilancio di Sostenibilità

Bilancio di Sostenibilità

Sustainable Development Report

Bilancio di Sostenibilità

Rapporto annuale

Bilancio di Sostenibilità

Bilancio di Sostenibilità

Bilancio di Sostenibilità

Bilancio di Sostenibilità

$152 \quad 480$

$\begin{array}{lll}156 & 262 & 484\end{array}$


both coding and measure disclosure. Text units refer to pieces of information within the context of the sentence; therefore, within a sentence (from dot to dot), it is possible to identify different sub-categories. For the purpose of this paper, we adopted text units as both coding units and units of measurement (Milne and Adler 1999; Pesci and Costa 2014).

We selected the categories used in the analysis for the environmental and employee issues based on the G3 Sustainability Reporting Guidelines developed by the Global Reporting Initiative (GRI) (G3 2011). We made this selection due to the complete absence of guidelines in the Italian D.Lgs. 32/2007 (Sirimarco 2007). However, whenever both the consolidated annual report and the stand-alone social and environmental reports included further information not provided in the $\mathrm{G} 3$ guidelines, we adopted an emergent coding (Haney et al. 1998) in order to cover each of the areas of the disclosure regarding employee and environmental matters. At the end of the coding process, we defined 11 categories for the environment ( $8 \mathrm{GRI}$ and 3 emerging codes) and 11 for the employee ( $5 \mathrm{GRI}$ and 6 emerging codes), as described in Tables $A 1$ and $A 2$ in the Appendix.

In order to guarantee reliability (Gray, Kouhy, and Lavers 1995; Unerman 2000), we carried out a pilot test on a few corporate social reports. We used at least three coders and re-analysed discrepancies between them to resolve differences (Milne and Adler 1999).

\subsection{Variables}

We selected four main variables for the content analysis of environmental aspects and employee issues. The volume of the disclosure (VOLUME) was measured by the number of text units referring to all social and environmental indicators presented in the consolidated financial and social-environmental reports.

The second variable investigated the completeness of disclosure (COMPLETENESS) in order to measure how listed corporate groups discharge accountability. By adopting a scoring system, several studies have attempted to build a measure of disclosure more complete and comprehensive than simple binary code (present or absent) (Hooks and Van Staden 2011). However, other researchers criticise these approaches, arguing that this kind of scoring may increase the subjectivity of the content analysis (Botosan 2004). For this reason, this paper employs an extent-based content analysis and divides the volume into levels of detail for the information: mention, description or evaluation. The completeness variable is not a score-point system, but simply measures how many text units are presented vaguely (mention), descriptively and exhaustively (description), or numerically (evaluation).

Consistent with other studies (Deegan and Gordon 1996; Deegan and Rankin 1996; Guthrie and Parker 1990), we have also evaluated whether Italian-listed corporate groups present information which is favourable (or not) to their corporate image (GOOD and BAD NEWS). For this reason, we investigated the number of text units that contribute to improving corporate image and reputation by presenting initiatives that positively affected the environment and employees. We have also considered bad news by analysing how many corporate groups devoted text units to negative impacts on environmental or employee matters. Previous studies have demonstrated that companies are usually more likely to disclose details on social and environmental issues that present them in a positive 
Table 2. Variables employed in the analysis

\begin{tabular}{|c|c|c|}
\hline Variable & Category & Example \\
\hline \multirow[t]{3}{*}{ Completeness } & Mention & $\begin{array}{l}\text { 'In almost all municipalities, the cleanliness of the public environment is also } \\
\text { guaranteed.' }\end{array}$ \\
\hline & Description & $\begin{array}{l}\text { 'All operations follow established procedures in accordance with the company } \\
\text { doctor, the Internal Service for Prevention and Protection and Health Services } \\
\text { Company experts responsible for the area. Technicians are always consulted, } \\
\text { especially in non-conventional cases.' }\end{array}$ \\
\hline & Evaluation & $\begin{array}{l}\text { 'In } 2005 \text {, more than } 120,000 \text { hours of training have been provided to staff, with a } \\
\text { total investment of about } € 2.9 \text { m.' }\end{array}$ \\
\hline \multirow[t]{3}{*}{ Good/bad news } & Good news & $\begin{array}{l}\text { 'The commitment to organizational and educational issues has been positively } \\
\text { reflected in accidents: in } 2005 \text {, the number of accidents in the unit of Trieste } \\
\text { was } 39 \text { compared to } 58 \text { in } 2004(-32.75 \%) \text {, with a net improvement over the } \\
\text { previous year in the frequency index and the severity of injuries.' }\end{array}$ \\
\hline & $\begin{array}{c}\text { Neutral } \\
\text { news }\end{array}$ & $\begin{array}{l}\text { 'Employees who work in network construction are professionally trained and in } \\
\text { possession of licenses and certificates of competency and qualification.' }\end{array}$ \\
\hline & Bad news & $\begin{array}{l}\text { 'As a consequence of an improvement in the frequency, there is a significant } \\
\text { worsening in severity in the cement sector (+24\%). This sector reported fewer } \\
\text { injuries, but they were, on average, more severe.' }\end{array}$ \\
\hline \multirow[t]{3}{*}{$\begin{array}{l}\text { Target-oriented } \\
\text { information }\end{array}$} & Past & $\begin{array}{l}\text { 'The volume of gas injected into the system in Trieste in } 2005 \text { was approximately } \\
179.3 \text { million cubic meters, an increase of } 3.9 \% \text { over the previous year.' }\end{array}$ \\
\hline & Present & $\begin{array}{l}\text { 'Workers with a part-time contract - } 50 \% \text { ( } 14 \text { of } 26 \text { ) of whom are employed at } \\
\text { headquarters - are in no way discriminated against in the continuation and } \\
\text { development of their careers for the type of contract adopted.' }\end{array}$ \\
\hline & Future & $\begin{array}{l}\text { 'Reducing emissions in the atmosphere of corporate fleets (through methane, } \\
\text { biodiesel, hybrid, etc.): Target: } 20 \% \text { of vehicles should reduce environmental } \\
\text { impact by 2009.' }\end{array}$ \\
\hline
\end{tabular}

light (Criado-Jiménez et al. 2008; Deegan and Gordon 1996; Guthrie and Parker 1990). Companies generally do not provide 'bad news' about their activities (Guthrie and Parker 1990), and if they do, 'bad news' is presented less than half as often as 'good news' (Criado-Jiménez et al. 2008).

Finally, we have also considered whether the reported information refers to the past, the present or the future in an attempt to understand if listed corporate groups use these issues for prospective purposes (TARGET-ORIENTED INFORMATION). Hasseldine, Salama, and Toms (2005) have provided insight into the importance of using targets to monitor outcomes for Social and Environmental Accounting and Reporting information; therefore, this paper distinguishes between disclosures of environmental and employee matters based on time: giving past information (past), reporting on the year of reference (present) or forecasting the future (future).

For some brief examples of the variables used in the analysis, please refer to Table 2.

\subsection{Regression Model}

For the purposes of this study, we have analysed the main drivers of disclosure for environmental and employee matters, both in consolidated annual reports and in stand-alone social and environmental reports. We have conducted a detailed investigation into how much the 2007 regulation may explain differences in social and environmental accountability in Italian-listed groups.

The following regression model has been employed:

$$
Y_{i, t}=\beta_{0}+\beta_{1} \mathrm{REGUL}_{i, t}+\beta_{2} \mathrm{SECTOR}_{i, t}+\beta_{3} \mathrm{BOTH}_{i, t}+e_{i, t},
$$


where $Y_{i, t}$ is the dependent variable referring to the different variables (mention, description, evaluation, good news, bad news, ${ }^{1}$ past, present and future) both for environmental and employee matters. REGUL ${ }_{i, t}$ is a dummy variable indicating the regulation. $\mathrm{REGUL}_{i, t}=0$ before regulation (2005) and $\mathrm{REGUL}_{i, t}=1$ after regulation (2010). SECTOR is a dummy variable indicating the activity sector of the group, which could be sensitive or not sensitive to the environment. SECTOR ${ }_{i, t}=0$ if it is not an environmentally impactful sector, and $\mathrm{SECTOR}_{i, t}=1$ if it is an environmentally impactful sector. $\mathrm{BOTH}_{i, t}$ is a dummy variable indicating the combined effect of the regulation and sector of activity. $\mathrm{BOTH}_{i, t}=0$ if either the regulation or sector of activity has no impact on the $Y$ variable and $\mathrm{BOTH}_{i, t}=1$ otherwise. $e_{i, t}$ is the term error.

If the regulation has no impact on the companies' disclosure, general model (1) could be simplified in model (2) as follows:

$$
\begin{gathered}
\mathrm{H}_{0}: \text { REGUL }_{i, t} \text { and BOTH } \\
Y_{i, t}=0 \\
Y_{i, t}=\beta_{0}+\beta_{2} \text { SECTOR }_{i, t}+e_{i, t} .
\end{gathered}
$$

We compare the two models by applying Pearson's correlation and the $F$ test to the tested regressions in order to investigate whether the regulation was a significant driver in changing the social and environmental disclosures of Italian companies from 2005 to 2010.

\section{Findings and Discussion}

\subsection{Environmental and Employee Information for Italian-Listed Corporate Groups}

Table 3 shows the overall number of text units presented both in stand-alone social and environmental reports and in consolidated annual reports in 2005 and 2010 by considering the different sub-categories within the environmental and employee matters. Overall, 21,820 text units have been manually analysed (9168 in 2005 and 12,652 in 2010), and most of the disclosures regarding social and environmental matters were located within the stand-alone social and environmental reports ( $80 \%$ in 2005 and $83 \%$ in 2010).

The analysis reveals an increase of 38\% between 2005 and 2010 in the overall volume of disclosure; this increase varied in the stand-alone report $(+43 \%)$ and the consolidated annual report (+20\%).

In considering the two main areas of investigation - employee and environmental matters - the analysis shows that these two dimensions are equally important. In 2005, 4512 text units (49\% of the overall disclosures that year) referred to environmental matters, and 4656 text units (51\%) concerned employee matters. In 2010, 6485 text units (51\% of the overall disclosures that year) referred to environmental matters, and the remaining 6167 (49\%) covered employee matters.

Table 3 clearly shows that some sub-categories are dominant within each category, with some variation between the consolidated annual report and the stand-alone social and environmental report. In general, with reference to environmental concerns, companies disclose more on emissions and energy (both in 2005 and in 2010). With regard to employee matters, companies provide more information regarding training and education programmes as well as their internal policies. 
Table 3. The overall volume of disclosures on employees and the environment by year and type of report

\begin{tabular}{|c|c|c|c|c|c|c|}
\hline \multirow[b]{2}{*}{ Environment } & \multicolumn{3}{|c|}{2005} & \multicolumn{3}{|c|}{2010} \\
\hline & $\begin{array}{l}\text { Social } \\
\text { report }\end{array}$ & $\begin{array}{l}\text { Consolidated annual } \\
\text { report }\end{array}$ & Total & $\begin{array}{l}\text { Social } \\
\text { report }\end{array}$ & $\begin{array}{l}\text { Consolidated annual } \\
\text { report }\end{array}$ & Total \\
\hline Materials & 155 & 97 & 252 & 257 & 31 & 288 \\
\hline Energy & 413 & 46 & 459 & 810 & 166 & 976 \\
\hline Water & 188 & 3 & 191 & 336 & 9 & 345 \\
\hline Biodiversity & 65 & 0 & 65 & 153 & 12 & 165 \\
\hline Emissions & 718 & 85 & 803 & 1339 & 110 & 1449 \\
\hline Products and services & 56 & 16 & 72 & 138 & 97 & 235 \\
\hline Compliance & 49 & 0 & 49 & 88 & 2 & 90 \\
\hline Transport & 98 & 0 & 98 & 213 & 3 & 216 \\
\hline Overall & 215 & 72 & 287 & 299 & 80 & 379 \\
\hline Quality & 225 & 60 & 285 & 207 & 97 & 304 \\
\hline General aspect & 1453 & 498 & 1951 & 1449 & 589 & 2038 \\
\hline Total & 3635 & 877 & 4512 & 5289 & 1196 & 6485 \\
\hline \multicolumn{7}{|l|}{ Employee } \\
\hline Emlpoyment & 284 & 98 & 382 & 366 & 158 & 524 \\
\hline $\begin{array}{l}\text { Labour/management } \\
\text { relations }\end{array}$ & 307 & 23 & 330 & 489 & 22 & 511 \\
\hline $\begin{array}{l}\text { Occupational health and } \\
\text { safety }\end{array}$ & 439 & 46 & 485 & 746 & 138 & 884 \\
\hline Training and education & 716 & 298 & 1014 & 1082 & 330 & 1412 \\
\hline $\begin{array}{l}\text { Diversity and equal } \\
\text { opportunity }\end{array}$ & 189 & 3 & 192 & 422 & 3 & 425 \\
\hline Development politics & 901 & 83 & 984 & 1237 & 77 & 1314 \\
\hline Social initiatives & 275 & 287 & 562 & 294 & 172 & 466 \\
\hline Communications & 490 & 103 & 593 & 414 & 77 & 491 \\
\hline Company's climate & 98 & 0 & 98 & 102 & 0 & 102 \\
\hline Questions of law & 16 & 0 & 16 & 38 & 0 & 38 \\
\hline Total & 3715 & 941 & 4656 & 5190 & 977 & 6167 \\
\hline Total volume & 7350 & 1818 & 9168 & 10,479 & 2173 & 12,652 \\
\hline
\end{tabular}

Tables 4-6 show the number of text units devoted to each of the variables identified for analysis, including completeness, bad/good news and target information.

By analysing the completeness of environmental and employee themes, Table 4 shows that, from 2005 to 2010, both numerical and descriptive information has increased. In more detail, the number of quantitative issues increased from 1814 in 2005 to 2673 in 2010 , and the number of descriptive issues increased from 6006 to 8686 . Differences also emerge when considering environmental and employee matters separately. With regard to environmental issues, the analysis reveals that, from 2005 to 2010, this information improved in terms of completeness because companies provided an increasing number of quantitative $(+4 \%)$ and descriptive $(+4 \%)$ information instead of vague and mentioned $(-7 \%)$ details. By comparison, the analysis regarding employee matters shows that more text units were devoted to explaining the impact of companies' internal policies on the workers; however, these narratives remained primarily descriptive in nature (70\% in 2010).

Therefore, in analysing the completeness of the data, the research shows that, generally speaking, disclosures became more complete from 2005 to 2010; however, the impact of these changes has been stronger for environmental matters.

By analysing the presence or absence of good and bad news, this study is consistent with other research (Criado-Jiménez et al. 2008; Deegan and Gordon 1996; Guthrie and Parker 1990). Italian-listed companies are indeed more likely to give accounts of good 
Table 4. The extent of completeness

\begin{tabular}{|c|c|c|c|c|c|c|c|c|c|}
\hline \multirow{2}{*}{ Completeness } & & \multicolumn{2}{|c|}{ Mention } & \multicolumn{2}{|c|}{ Description } & \multicolumn{2}{|c|}{ Evaluation } & \multicolumn{2}{|c|}{ Total } \\
\hline & & 2005 & 2010 & 2005 & 2010 & 2005 & 2010 & 2005 & 2010 \\
\hline \multirow[t]{6}{*}{ Environment } & Social reports & 350 & 265 & 2417 & 3512 & 868 & 1512 & 3635 & 5289 \\
\hline & & $10 \%$ & $5 \%$ & $66 \%$ & $66 \%$ & $24 \%$ & $29 \%$ & $100 \%$ & $100 \%$ \\
\hline & Consolidated annual reports & 384 & 315 & 488 & 879 & 5 & 2 & 877 & 1196 \\
\hline & & $43 \%$ & $26 \%$ & $56 \%$ & $74 \%$ & $1 \%$ & $0,2 \%$ & $100 \%$ & $100 \%$ \\
\hline & $\Sigma$ & 734 & 580 & 2905 & 4319 & 873 & 1514 & 4512 & 6485 \\
\hline & & $16 \%$ & $9 \%$ & $64 \%$ & $68 \%$ & $19 \%$ & $23 \%$ & $100 \%$ & $100 \%$ \\
\hline \multirow[t]{6}{*}{ Employees } & Social reports & 252 & 292 & 2525 & 3740 & 938 & 1158 & 3715 & 5190 \\
\hline & & $7 \%$ & $6 \%$ & $68 \%$ & $72 \%$ & $25 \%$ & $22 \%$ & $100 \%$ & $100 \%$ \\
\hline & Consolidated annual reports & 362 & 421 & 576 & 555 & 3 & 1 & 941 & 977 \\
\hline & & $38 \%$ & $43 \%$ & $61 \%$ & $57 \%$ & $0 \%$ & $0 \%$ & $100 \%$ & $100 \%$ \\
\hline & $\Sigma$ & 614 & 713 & 3101 & 4295 & 941 & 1159 & 4656 & 6167 \\
\hline & & $13 \%$ & $12 \%$ & $67 \%$ & $70 \%$ & $20 \%$ & $19 \%$ & $100 \%$ & $100 \%$ \\
\hline \multirow[t]{6}{*}{ Total } & Social reports & 602 & 557 & 4942 & 7252 & 1806 & 2670 & 7350 & 10,479 \\
\hline & & $8 \%$ & $5 \%$ & $67 \%$ & $69 \%$ & $25 \%$ & $25 \%$ & $100 \%$ & $100 \%$ \\
\hline & Consolidated annual reports & 746 & 736 & 1064 & 1434 & 8 & 3 & 1818 & 2173 \\
\hline & & $41 \%$ & $34 \%$ & $59 \%$ & $66 \%$ & $0 \%$ & $0 \%$ & $100 \%$ & $100 \%$ \\
\hline & $\Sigma$ & 1348 & 1293 & 6006 & 8686 & 1814 & 2673 & 9168 & 12,652 \\
\hline & & $15 \%$ & $10 \%$ & $65 \%$ & $69 \%$ & $20 \%$ & $21 \%$ & $100 \%$ & $100 \%$ \\
\hline
\end{tabular}

news (6\% in 2010) instead of bad news (0.6\% in 2010). Table 5 shows that from 2005 to 2010, both good news and bad news slightly decreased, but there was a large difference between them: bad news continued to be underrepresented both in consolidated annual reports and in social and environmental reports. Contrarily, good news was depicted in $6 \%$ (in 2010) of the total disclosures and was more apparent in the consolidated annual reports.

The data also show differing patterns for environmental and employee matters. Generally speaking, in 2005, bad news disclosures were mostly made in regard to employee issues (55\% of the total bad news in 2005); in 2010, there was more bad news related to the environment (53\%).

Table 5. The extent of bad and good news

\begin{tabular}{|c|c|c|c|c|c|c|c|c|c|}
\hline \multirow{2}{*}{\multicolumn{2}{|c|}{ Bad and good News }} & \multicolumn{2}{|c|}{ Neutral } & \multicolumn{2}{|c|}{ Bad } & \multicolumn{2}{|c|}{ Good } & \multicolumn{2}{|c|}{ Total } \\
\hline & & 2005 & 2010 & 2005 & 2010 & 2005 & 2010 & 2005 & 2010 \\
\hline \multirow[t]{6}{*}{ Environment } & Social reports & 3475 & 4985 & 18 & 28 & 142 & 276 & 3635 & 5289 \\
\hline & & $96 \%$ & $94 \%$ & $1 \%$ & $1 \%$ & $4 \%$ & $5 \%$ & $100 \%$ & $100 \%$ \\
\hline & Consolidated annual reports & 652 & 927 & 11 & 13 & 214 & 256 & 877 & 1196 \\
\hline & & $74 \%$ & $78 \%$ & $1 \%$ & $1 \%$ & $24 \%$ & $21 \%$ & $100 \%$ & $100 \%$ \\
\hline & $\sum$ & 4127 & 5912 & 29 & 41 & 356 & 532 & 4512 & 6485 \\
\hline & & $91 \%$ & $91 \%$ & $1 \%$ & $1 \%$ & $8 \%$ & $8 \%$ & $100 \%$ & $100 \%$ \\
\hline \multirow[t]{6}{*}{ Employees } & Social reports & 3612 & 5068 & 30 & 20 & 73 & 102 & 3715 & 5190 \\
\hline & & $97 \%$ & $98 \%$ & $1 \%$ & $0 \%$ & $2 \%$ & $2 \%$ & $100 \%$ & $100 \%$ \\
\hline & Consolidated annual reports & 698 & 778 & 6 & 16 & 237 & 183 & 941 & 977 \\
\hline & & $74 \%$ & $80 \%$ & $1 \%$ & $2 \%$ & $25 \%$ & $19 \%$ & $100 \%$ & $100 \%$ \\
\hline & $\sum$ & 4310 & 5846 & 36 & 36 & 310 & 285 & 4656 & 6167 \\
\hline & & $93 \%$ & $95 \%$ & $1 \%$ & $1 \%$ & $7 \%$ & $5 \%$ & $100 \%$ & $100 \%$ \\
\hline \multirow[t]{6}{*}{ Total } & Social reports & 7087 & 10,053 & 48 & 48 & 215 & 378 & 7350 & 10479 \\
\hline & & $96 \%$ & $96 \%$ & $1 \%$ & $0 \%$ & $3 \%$ & $4 \%$ & $100 \%$ & $100 \%$ \\
\hline & Consolidated annual reports & 1350 & 1705 & 17 & 29 & 451 & 439 & 1818 & 2173 \\
\hline & & $74 \%$ & $78 \%$ & $1 \%$ & $1 \%$ & $25 \%$ & $20 \%$ & $100 \%$ & $100 \%$ \\
\hline & $\Sigma$ & 8437 & 11,758 & 65 & 77 & 666 & 817 & 9168 & 12,652 \\
\hline & & $92 \%$ & $93 \%$ & $0.7 \%$ & $0.6 \%$ & $7 \%$ & $6 \%$ & $100 \%$ & $100 \%$ \\
\hline
\end{tabular}


Table 6. The extent of target-oriented information

\begin{tabular}{|c|c|c|c|c|c|c|c|c|c|}
\hline \multirow{2}{*}{\multicolumn{2}{|c|}{ Target-oriented information }} & \multicolumn{2}{|c|}{ Past } & \multicolumn{2}{|c|}{ Present } & \multicolumn{2}{|c|}{ Future } & \multicolumn{2}{|c|}{ Total } \\
\hline & & 2005 & 2010 & 2005 & 2010 & 2005 & 2010 & 2005 & 2010 \\
\hline \multirow[t]{6}{*}{ Environment } & Social reports & 225 & 374 & 3270 & 4764 & 140 & 151 & 3635 & 5289 \\
\hline & & $6 \%$ & $7 \%$ & $90 \%$ & $90 \%$ & $4 \%$ & $3 \%$ & $100 \%$ & $100 \%$ \\
\hline & Consolidated annual reports & 551 & 734 & 255 & 391 & 71 & 71 & 877 & 1196 \\
\hline & & $62 \%$ & $61 \%$ & $29 \%$ & $32 \%$ & $8 \%$ & $6 \%$ & $100 \%$ & $100 \%$ \\
\hline & $\Sigma$ & 776 & 1108 & 3525 & 5155 & 211 & 222 & 4512 & 6485 \\
\hline & & $17 \%$ & $17 \%$ & $78 \%$ & $79 \%$ & $5 \%$ & $3 \%$ & $100 \%$ & $100 \%$ \\
\hline \multirow[t]{6}{*}{ Employees } & Social reports & 162 & 240 & 3413 & 4749 & 140 & 201 & 3715 & 5190 \\
\hline & & $4 \%$ & $5 \%$ & $92 \%$ & $92 \%$ & $4 \%$ & $4 \%$ & $100 \%$ & $100 \%$ \\
\hline & Consolidated annual reports & 643 & 685 & 266 & 282 & 32 & 10 & 941 & 977 \\
\hline & & $68 \%$ & $70 \%$ & $28 \%$ & $29 \%$ & $3 \%$ & $1 \%$ & $100 \%$ & $100 \%$ \\
\hline & $\Sigma$ & 805 & 925 & 3679 & 5031 & 172 & 211 & 4656 & 6167 \\
\hline & & $17 \%$ & $15 \%$ & $79 \%$ & $82 \%$ & $4 \%$ & $3 \%$ & $100 \%$ & $100 \%$ \\
\hline \multirow[t]{6}{*}{ Total } & Social reports & 387 & 614 & 6683 & 9513 & 280 & 352 & 7350 & 10,479 \\
\hline & & $5 \%$ & $6 \%$ & $91 \%$ & $91 \%$ & $4 \%$ & $3 \%$ & $100 \%$ & $100 \%$ \\
\hline & Consolidated annual reports & 1194 & 1419 & 521 & 673 & 103 & 81 & 1818 & 2173 \\
\hline & & $65 \%$ & $65 \%$ & $29 \%$ & $31 \%$ & $6 \%$ & $4 \%$ & $100 \%$ & $100 \%$ \\
\hline & $\Sigma$ & 1581 & 2033 & 7204 & 10,186 & 383 & 433 & 9168 & 12,652 \\
\hline & & $17 \%$ & $16 \%$ & $79 \%$ & $81 \%$ & $4 \%$ & $3 \%$ & $100 \%$ & $100 \%$ \\
\hline
\end{tabular}

Finally, the analysis of target-oriented information in Table 6 shows that companies tend to focus their reports on the present year with less attention to previous years (17\% in 2005 and 16\% in 2010) and target-oriented news (4\% in 2005 and 3\% in 2010).

This trend is most evident in stand-alone social and environmental reports rather than in consolidated annual reports. As suggested by Riccaboni and Leone (2010), companies remain unable to reach their full potential of embedding social and environmental issues within their management control systems (MCSs) because these formal tools are often exclusively focused on financial issues.

By comparing environmental and employee matters, Table 6 shows that few differences emerge between the two areas of disclosure.

\subsection{Pearson's Correlation and Regression Analysis}

The analysis shows that there are no significant linear relationships between the examined variables and the 2007 regulation. Taking into account the interaction between the two mentioned variables (activity sector sensitivity and 2007 regulation), we obtain some positive significant relationships (Table 7).

After applying Pearson's correlation coefficient, we may investigate the activity sector sensitivity impact (as an independent variable) by applying regression models (1) (Table 8) and (2) (Table 8 ) to the completeness, good/bad news and target-oriented information.

Tables 8 and 9 indicate how well we have explained the dependent variables in terms of three independent variables: the 2007 regulation, the environmentally impactful sector and their interaction. The $R$-squared is not high, which means that the model does not fit the data well. The ANOVA table indicates that there is a significant linear relationship between the dependent variable and the explanatory variable (we have a significant linear equation because the $P$-value is equal to .000). We used an $F$ test to test the null hypothesis that there would be no linear relationship, and we compared the two 
Table 7. Pearson correlation

\begin{tabular}{|c|c|c|c|c|c|c|c|c|c|c|c|c|c|}
\hline & & Regulation & Sector & Both & Report & Mention & Description & Evaluation & Good & Bad & Past & Present & Future \\
\hline \multirow[t]{2}{*}{ Regulation } & Pearson Corr. & 1 & .000 & $.447^{* *}$ & .000 & -.019 & .188 & .131 & .095 & .040 & .112 & .145 & .035 \\
\hline & Sign. (2-tailed) & & 1.000 & .000 & 1.000 & .855 & .066 & .205 & .356 & .698 & .278 & .158 & .734 \\
\hline \multirow[t]{2}{*}{ Sector } & Pearson Corr. & .000 & 1 & $.632^{* *}$ & .000 & $.357^{* *}$ & $.267^{* *}$ & $.278^{* *}$ & $.311^{* *}$ & $.395^{* *}$ & $.434^{* *}$ & $.222^{*}$ & $.245^{*}$ \\
\hline & Sign. (2-tailed) & 1.000 & & .000 & 1.000 & .000 & .008 & .006 & .002 & .000 & .000 & .030 & .016 \\
\hline \multirow[t]{2}{*}{ Both } & Pearson Corr. & $.447^{* *}$ & $.632^{* *}$ & 1 & .000 & $.222^{*}$ & $.304^{* *}$ & $.268^{* *}$ & $.276^{* *}$ & $.228^{*}$ & $.419^{* *}$ & $.241^{*}$ & .058 \\
\hline & Sign. (2-tailed) & .000 & .000 & & 1.000 & .030 & .003 & .008 & .007 & .026 & .000 & .018 & .571 \\
\hline \multirow[t]{2}{*}{ Report } & Pearson Corr. & .000 & .000 & .000 & 1 & .111 & $-.682^{* *}$ & $-.679^{* *}$ & .187 & -.167 & $.398^{* *}$ & $-.730^{* *}$ & $-.315^{* *}$ \\
\hline & Sign. (2-tailed) & 1.000 & 1.000 & 1.000 & & .281 & .000 & .000 & .068 & .103 & .000 & .000 & .002 \\
\hline \multirow[t]{2}{*}{ Mention } & Pearson Corr. & -.019 & $.357^{* *}$ & $.222^{*}$ & .111 & 1 & $.271^{* *}$ & $.257^{*}$ & $.704^{* *}$ & $.389 * *$ & $.617^{* *}$ & $.268^{* *}$ & $.304^{* *}$ \\
\hline & Sign. (2-tailed) & .855 & .000 & .030 & .281 & & .008 & .011 & .000 & .000 & .000 & .008 & .003 \\
\hline \multirow[t]{2}{*}{ Description } & Pearson Corr. & .188 & $.267^{* *}$ & $.304^{* *}$ & $-.682^{* *}$ & $.271^{* *}$ & 1 & $.909^{* *}$ & $.298^{* *}$ & $.386^{* *}$ & .093 & $.970^{* *}$ & $.482^{* *}$ \\
\hline & Sign. (2-tailed) & .066 & .008 & .003 & .000 & .008 & & .000 & .003 & .000 & .368 & .000 & .000 \\
\hline \multirow[t]{2}{*}{ Evaluation } & Pearson Corr. & .131 & $.278^{* *}$ & $.268^{* *}$ & $-.679^{* *}$ & $.257^{*}$ & $.909^{* *}$ & 1 & $.203^{*}$ & $.452^{* *}$ & -.045 & $.960^{* *}$ & $.503^{* *}$ \\
\hline & Sign. (2-tailed) & .205 & .006 & .008 & .000 & .011 & .000 & & .048 & .000 & .661 & .000 & .000 \\
\hline \multirow[t]{2}{*}{ Good } & Pearson Corr. & .095 & $.311^{* *}$ & $.276^{* *}$ & .187 & $.704^{* *}$ & $.298^{* *}$ & $.203^{*}$ & 1 & $.309^{* *}$ & $.761^{* *}$ & $.205^{*}$ & $.225^{*}$ \\
\hline & Sign. (2-tailed) & .356 & .002 & .007 & .068 & .000 & .003 & .048 & & .002 & .000 & .045 & .027 \\
\hline \multirow[t]{2}{*}{ Bad } & Pearson Corr. & .040 & $.395^{* *}$ & $.228^{*}$ & -.167 & $.389^{* *}$ & $.386^{* *}$ & $.452^{* *}$ & $.309^{* *}$ & 1 & .189 & $.407^{* *}$ & $.327^{* *}$ \\
\hline & Sign. (2-tailed) & .698 & .000 & .026 & .103 & .000 & .000 & .000 & .002 & & .065 & .000 & .001 \\
\hline \multirow[t]{2}{*}{ Past } & Pearson Corr. & .112 & $.434^{* *}$ & $.419^{* *}$ & $.398^{* *}$ & $.617^{* *}$ & .093 & -.045 & $.761^{* *}$ & .189 & 1 & -.071 & .166 \\
\hline & Sign. (2-tailed) & .278 & .000 & .000 & .000 & .000 & .368 & .661 & .000 & .065 & & .490 & .106 \\
\hline \multirow[t]{2}{*}{ Present } & Pearson Corr. & .145 & $.222^{*}$ & $.241^{*}$ & $-.730^{* *}$ & $.268^{* *}$ & $.970^{* *}$ & $.960^{* *}$ & $.205^{*}$ & $.407^{* *}$ & -.071 & 1 & $.436^{* *}$ \\
\hline & Sign. (2-tailed) & .158 & .030 & .018 & .000 & .008 & .000 & .000 & .045 & .000 & .490 & & .000 \\
\hline \multirow[t]{2}{*}{ Future } & Pearson Corr. & .035 & $.245^{*}$ & .058 & $-.315^{* *}$ & $.304^{* *}$ & $.482^{* *}$ & $.503^{* *}$ & $.225^{*}$ & $.327^{* *}$ & .166 & $.436^{* *}$ & 1 \\
\hline & Sign. (2-tailed) & .734 & .016 & .571 & .002 & .003 & .000 & .000 & .027 & .001 & .106 & .000 & \\
\hline
\end{tabular}

Note: $N=96$.

*The correlation is .05 significant (2-tailed).

**The correlation is .01 significant (2-tailed). 
Table 8. Regression analysis: Model 1 Model 1

\begin{tabular}{|c|c|c|c|c|c|c|c|c|c|}
\hline$R$ & 0.359 & & & & & & & & \\
\hline$R$-squared & 0.129 & & & & & & & & \\
\hline$R$-squared corrected & 0.101 & & & & & & & & \\
\hline Standard deviation & 212.16809 & & & & & & & & \\
\hline \multirow[t]{3}{*}{$N$} & 96 & & & & & & & & \\
\hline & \multicolumn{3}{|c|}{ Regulation } & \multicolumn{3}{|c|}{ Sector } & \multicolumn{3}{|c|}{ Both } \\
\hline & Beta & $t$ & Sig. & Beta & $t$ & Sig. & Beta & $t$ & Sig. \\
\hline Overall volume & 0.113 & 0.95 & 0.345 & 0.241 & 1.755 & 0.083 & 0.112 & 0.725 & 0.47 \\
\hline Mention & -0.024 & -0.199 & 0.842 & 0.35 & 2.543 & 0.013 & 0.011 & 0.07 & 0.944 \\
\hline Description & 0.132 & 1.098 & 0.275 & 0.188 & 1.351 & 0.18 & 0.126 & 0.812 & 0.419 \\
\hline Evaluation & 0.093 & 0.763 & 0.447 & 0.224 & 1.599 & 0.113 & 0.085 & 0.542 & 0.589 \\
\hline Good news & 0.055 & 0.455 & 0.65 & 0.254 & 1.351 & 0.18 & 0.09 & 0.58 & 0.563 \\
\hline Bad news & 0.085 & 0.73 & 0.467 & 0.459 & 3.401 & 0.001 & -0.101 & -0.669 & 0.505 \\
\hline Past-oriented & 0.006 & 0.053 & 0.958 & 0.284 & 2.187 & 0.031 & 0.237 & 1.628 & 0.107 \\
\hline Present-oriented & 0.105 & 0.857 & 0.393 & 0.166 & 1.169 & 0.245 & 0.089 & 0.559 & 0.577 \\
\hline Target-oriented & 0.16 & 1.317 & 0.191 & 0.421 & 3.001 & 0.003 & -0.28 & -1.781 & 0.078 \\
\hline
\end{tabular}


Table 9. Regression analysis: Model 2

\begin{tabular}{lccc}
\hline Model 2 & & & \\
\hline$R$ & 0.312 & & \\
$R$-squared & 0.097 & & \\
$R$-squared corrected & 0.088 & & \\
Standard deviation & 213.66911 & & Sig. \\
$N$ & 96 & Sector & 0.002 \\
& & $t$ & 0 \\
& Beta & 3.184 & 0.008 \\
Overall volume & 0.312 & 3.705 & 0.006 \\
Mention & 0.357 & 2.69 & 0.002 \\
Description & 0.267 & 2.803 & 0 \\
Evaluation & 0.278 & 3.175 & 0 \\
Good news & 0.311 & 4.171 & 0.03 \\
Bad news & 0.395 & 4.668 & 0.016 \\
Past-oriented & 0.434 & 2.208 & \\
Present-oriented & 0.222 & 2.445 & \\
Future-oriented & 0.245 & & \\
& & & \\
\hline
\end{tabular}

previously described models (1) and (2). We have the evidence that there is a significant linear relationship with a significance value (Prob $>F$ ) of less than .05 .

Moreover, looking at the columns entitled $t$ and Sig., we see that all regressions indicate that model 2 fits the data because the environmental impactful sector of activity better explains the variations in the extent of disclosure about employee and environmental matters from 2005 to 2010.

\section{Concluding Remarks}

This paper provides an opportunity to reflect on environmental and employee matters in both the consolidated annual reports and stand-alone social and environmental reports of Italian-listed companies from 2005 to 2010. It also has investigated whether or not the new Italian D.Lgs. 32/2007 explains these changes.

Italian D.Lgs. 32/2007 introduced European Directive 2003/51/EC in Italy, representing the first national attempt to compel corporate groups to include information regarding environmental and employee matters in their consolidated annual reports. The broadness and vagueness of this Italian regulation makes its application burdensome and informally allows companies to omit social and environmental information within a unique report, leaving them separate (Sirimarco 2007).

By considering both consolidated annual reports and stand-alone social and environmental reports, our analysis reveals that, from 2005 to 2010, companies disclosed more regarding their environmental and employee impacts. We observed an increase of $+38 \%$ in the overall disclosure and an improvement in terms of information completeness. Indeed, the amount of both descriptive and quantitative information increased from 2005 to $2010(+4 \%$ and $+1 \%$, respectively), while the number of the vaguest sentences decreased $(-5 \%)$. Such information remained anchored to portraying a positive view of the company (Criado-Jiménez et al. 2008; Deegan and Gordon 1996; Guthrie and Parker $1990)$ through the presence of more good news (6\%) than bad news (0.06\%). Finally, companies did not integrate information regarding social and environmental concerns within their strategy and MCSs because these tools have a minimal ability to provide a complete 
overview of the future impact of business activities (future-oriented information was $3 \%$ in 2010).

The analysis also shows differences between the two main areas of investigation, the environment and employee matters. Both are equally represented in corporate groups' overall disclosures, but there were differences in terms of the kind of disclosures. Environmental disclosures significantly improved from 2005 to 2010 in terms of completeness; there were more disclosures in 2010, and they were more detailed and quantitative. Moreover, in 2010, there were more bad and good news reports regarding the environment compared to employee matters.

In order to better understand the meaning of this change, our research investigated the role of regulation in increasing these disclosures. The regression analysis shows that Italian D.Lgs. 32/2007 cannot be considered responsible for these changes.

Why has the Italian regulation been ineffective in promoting this change? What other factors could be influencing it?

In order to answer the first question, further research could investigate the relationships and dynamics between the regulation and the institutional context of this country. To this end, we also encourage future researchers to develop a longitudinal analysis - addressing one of the limitations of the current research - and to better explore the relationship between different kinds of reports.

Previous studies have provided various explanations for why regulations sometimes do not provide the expected outcome (Adams 2004; Bebbington and Thy 1999; Jeffrey and Perkins 2013; Larrinaga et al. 2002; Owen, Gray, and Bebbington 1997). Here, we would like to suggest two possibilities for the Italian case, both of which require further investigation. First, mandatory social and environmental disclosure could have been perceived as mere administrative reform rather than institutional change (Larrinaga et al. 2002; Owen, Gray, and Bebbington 1997). In this sense, when a stakeholder engagement process is lacking, authors observe administrative reform rather than institutional transformation (Bebbington and Thy 1999; Larrinaga et al. 2002).

In the Italian case, the complete absence of stakeholder dialogue, together with the ambiguity of D.Lgs. 32/2007, prevents increased transparency in social and environmental information and increased company awareness regarding impacts on society.

In more detail, our analysis has revealed that D.Lgs. 32/2007 is incapable of introducing an integration process for financial, environmental and employee concerns into Italian corporate groups' operations and strategies. As Sirimarco (2007) posited, the potential of considering a plethora of additional relevant information to enrich the effectiveness of disclosure has been reduced to a 'mere annex' to consolidated financial statements.

These circumstances lead us to believe that Italian D.Lgs. 32/2007 is far from an institutional reform; it requires more stakeholder dialogue and engagement to facilitate a fair process of accountability.

Second, in order to avoid mandated regulation being perceived as a 'top-down' process of formal standard setting and legal enforcement, Jeffrey and Perkins (2013) suggest a hybrid approach that 'combines a dialogical process based on broader participation, representation of and respect for divergent views and outcomes that are designed to reflect these divergent views for determining disclosure metrics combined with mandated disclosure' (16). 
In the light of these reflections, we perceive that Italy remains far from acknowledging the importance of stakeholder engagement in designing legislative processes. In Italy, a passive approach to regulation prevails (Sirimarco 2007), according to which regulators decide and companies oblige. On the contrary, the European working group on the disclosure of non-financial information recognised the importance of creating a dialogue with stakeholders and designing regulations on the basis of their suggestions. In 2013, the working group declared that:

the current approach to the disclosure of non-financial information in the Accounting Directives has not been sufficiently effective. A majority of stakeholders consulted considered that the obligation set by the Accounting Directives lacks clarity and may prejudice legal certainty. Clearer requirements and stronger focus on topical issues important for the company's long-term success are therefore necessary. (European Commission 2013/0110, 2)

As a consequence of this stakeholder engagement process, the recent 2014/95/EU made steps in this direction. Compared to 2003/51/EC, it is more focused and detailed, compelling organisations to provide a list of specific social and environmental information that has emerged during the previous 10 years of stakeholder dialogue.

What can be learnt from this paper is that the top-down approach adopted in Italy lacked a clear objective, content and stakeholder dialogue/process; these shortcomings may have caused the regulation to be ineffective and counterproductive. Further, the European community has to monitor the implementation process for its European Directive for member states: each member state has to replicate the collaborative and constructive approach that has been adopted elsewhere in Europe.

The second question this paper leaves open relates to other factors that may have influenced changes in disclosures between 2005 and 2010 in Italy. The results show that environmental disclosure has increased and improved more than employee disclosure. By reading the European legislative process guiding the European Commission's recent Directive 2014/95/EU, it is possible to observe that the Commission focused on the environment beginning with the 1992 'Toward Sustainability' document and continuing to the 2001 Recommendation (30 May 2001). The European Commission was convinced that 'an enhanced attention to financial aspects could contribute to achieving the goals of the programme; ensuring that environmental expenditures and risks are taken into account could increase the company's awareness of environmental issues' (point 1, 2001/453/EC).

We believe that this initial focus on environmental aspects could partially explain why Italian companies enhanced their disclosure on environmental concerns rather on employee matters. The process of increasing European companies' awareness of social and environmental impacts initially focused on climate change and environmental protection; this concentration potentially could have affected the environmental culture and sensitivity in which companies operate.

\section{Note}

1. Neutral news was not considered in the regression model because it was not relevant for the analysis. 


\section{References}

Adams, C. A. 2004. "The Ethical, Social and Environmental Reporting-performance Gap." Accounting, Auditing \& Accountability Journal 17 (5): 731-757.

Adams, C. A., A. Coutts, and G. Harte. 1995. "Corporate Equal Opportunities (non-) Disclosure." British Accounting Review 27: 87-108.

Al-Tuwaijri, S., T. E. Christensen, and K. E. Hughes. 2004. "The Relations among Environmental Disclosure, Environmental Performance, and Economic Performance: A Simultaneous Equations Approach." Accounting, Organizations and Society 29 (5-6): 447-471.

Andreaus, M. ed. 2007. La Rendicontazione Sociale Nei Gruppi Aziendali. Milan: McGraw Hill.

Beattie, V., and S. J. Thompson. 2007. "Lifting the Lid on the Use of Content Analysis to Investigate Intellectual Capital Disclosures." Accounting Forum 31 (2): 129-163.

Bebbington, J. 2007. Accounting for Sustainable Development Performance. London: CIMA Publishing, Elsevier.

Bebbington, J., and C. Thy. 1999. "Compulsory Environmental Reporting in Denmark: An Evaluation." Social and Environmental Accountability Journal 19 (2): 2-4.

Beets, S. D., and C. C. Souther. 1999. "Corporate Environmental Reports: The Need for Standards and an Environmental Assurance Service." Accounting Horizons 13 (2): 129-145.

Botosan, C. A. 2004. "Discussion of a Framework for the Analysis of Firm Risk Communication." The International Journal of Accounting 39: 289-295.

Brennan, N. M., E. Guillamon-Saorin, and A. Pierce. 2009. "Impression Management: Developing and Illustrating a Scheme of Analysis for Narrative Disclosures - A Methodological Note." Accounting, Auditing and Accountability Journal 22 (5): 789-832.

Criado-Jiménez, I., M. Fernàndez-Chuliàn, F. J. Husillos-Carqués, and C. Larrinaga-Gonzàlez. 2008. "Compliance with Mandatory Environmental Reporting in Financial Statements: The Case of Spain (2001-2003)." Journal of Business Ethics 79: 245-262.

Day, R., and T. Woodward. 2004. "Disclosure of Information about Employees in the Directors' Report of UK Published Financial Statements: Substantive or Symbolic?" Accounting Forum 28: 43-59.

Deegan, C., and B. Gordon. 1996. "A Study of the Environmental Disclosure Practices of Australian Corporations." Accounting and Business Research 23 (3): 187-199.

Deegan, C., and M. Rankin. 1996. “Do Australian Companies Report Environmental News Objectively? An Analysis of Environmental Disclosures by Firms Prosecuted Successfully by the Environmental Protection Authority." Accounting, Auditing and Accountability Journal 9 (2): 50-67.

European Commission. 2001. Commission Recommendation of 30 May 2001 on the recognition, measurement and disclosure of environmental issues in the annual accounts and annual reports of companies, 2001/453/EC. http://eur-lex.europa.eu/legal-content/EN/TXT/PDF/?uri= CELEX:32001H0453\&from=EN.

European Commission. 2013. Proposal for a Directive of the European Parliament and of the Council amending Council Directives 78/660/EEC and 83/349/EEC as regards disclosure of nonfinancial and diversity information by certain large companies and groups, 2013/0110. http://eur-lex.europa.eu/legal-content/ EN/TXT/PDF/?uri=CELEX:52013PC0207\&from=EN.

European Directive. 2003. Directive of the European Parliament and of the Council of 18 June 2003 amending Directives 78/660/EEC, 83/349/EEC, 86/635/EEC and 91/674/EEC on the annual and consolidated accounts of certain types of companies, banks and other financial institutions and insurance undertakings, 2003/51/EC. http://eur-lex.europa.eu/legal-content/EN/TXT/PDF/?uri= CELEX:32003L0051\&from=EN.

European Directive. 2014. Directive of the European Parliament and of the Council of 22 October 2014 amending Directive 2013/34/EU as regards disclosure of non-financial and diversity information by certain large undertakings and groups, 2014/95/EU. http://eur-lex.europa.eu/legalcontent/EN/TXT/PDF/?uri=CELEX:32001H0453\&from=EN.

Firoz, M., and A. A. Ansari. 2010. "Environmental Accounting and International Financial Reporting Standards (IFRS)." International Journal of Business and Management 5 (10): 105-108.

G3-GRI Global Reporting Initiative. 2011. Sustainability Reporting Guidelines. https://www. globalreporting.org/resourcelibrary/G3-Guidelines-Incl-Technical-Protocol.pdf. 
Gray, R. H. 2006. “Does Sustainability Reporting Improve Corporate Behavior? Wrong Questions? Right Time?" Accounting and Business Research International Accounting Policy Forum 36 (4): 65-88.

Gray, R. H., R. Kouhy, and S. Lavers. 1995. "Methodological Themes. Constructing a Research Database of Social and Environmental Reporting by UK Companies." Accounting, Auditing \& Accountability Journal 8 (2): 78-101.

Guthrie, J., and L. D. Parker. 1990. “Corporate Social Disclosure Practice: A Comparative International Analysis." Advances in Public Interest Accounting 3: 159-175.

Haney, Walt, Michael Russell, Cengiz Gulek, and Edward Fierros. 1998. "Drawing on Education: Using Student Drawings to Promote Middle School Improvement." Schools in the Middle 7 (3): 38-43.

Hasseldine, J., A. I. Salama, and J. S. Toms. 2005. "Quantity Versus Quality: The Impact of Environmental Disclosures on the Reputations of UK Plcs." The British Accounting Review 37: 231-248.

Hibbitt, C., and D. Collison. 2004. "Corporate Environmental Disclosure and Reporting Developments in Europe." Social and Environmental Accountability Journal 24 (1): 1-11.

Hooks, J., and C. J. Van Staden. 2011. "Evaluating Environmental Disclosures: The Relationship between Quality and Extent Measures." The British Accounting Review 43 (3): 200-213.

Jeffrey, C., and J. D. Perkins. 2013. "Social Norms and Disclosure Policy: Implications from a Comparison of Financial and Corporate Social Responsibility Reporting." Social and Environmental Accountability Journal 33 (1): 5-19.

Kolk, A. 2005. "Environmental Reporting by Multinationals from the Triad: Convergence or Divergence?" Management International Review 45: 145-166.

KPMG. 2011. KPMG. International Survey of Corporate Responsibility Reporting 2011. Amsterdam: KPMG.

Krippendorf, K. 1980. Content Analysis: An Introduction to Its Methodology. Beverly Hills, CA: Sage.

Larrinaga, C., F. Carrasco, C. Correa, F. Llena, and J. Moneva. 2002. "Accountability and Accounting Regulation: The Case of the Spanish Environmental Disclosure Standard." European Accounting Review 11 (4): 723-740.

Legislative Decree 32/2007 Attuazione della direttiva 2003/51/CE che modifica le direttive 78/660, $83 / 349$, 86/635 e 91/674/CEE relative ai conti annuali e ai conti consolidati di taluni tipi di societa', delle banche e altri istituti finanziari e delle imprese di assicurazione. (Pubblicato nella Gazzetta Ufficiale n. 73 del 28 marzo 2007).

Llena, F., J. M. Moneva, and B. Hernandez. 2007. "Environmental Disclosures and Compulsory Accounting Standards: The Case of Spanish Annual Reports." Business Strategy and the Environment 16 (1): 50-63.

Milne, M. J., and R. W. Adler. 1999. "Exploring the Reliability of Social and Environmental Disclosures Content Analysis." Accounting, Auditing \& Accountability Journal 12 (2): 237-252.

Mobus, J. L. 2005. "Mandatory Environmental Disclosures in a Legitimacy Theory Context." Accounting, Auditing \& Accountability Journal 18 (4): 492-517.

Owen, D., R. H. Gray, and J. Bebbington. 1997. "Green Accounting: Cosmetic Irrelevance or Radical Agenda for Change?" Asia-Pacific Journal of Accounting 4 (2): 175-198.

Parker, L. 2014. "Constructing a Research Field: A Reflection on the History of Social and Environmental Accounting." Social and Environmental Accountability Journal 34 (2): 87-92.

Pesci, C., and P. Andrei. 2011. "An Empirical Investigation into the Boundary of Corporate Social Reports and Consolidated Financial Statements." The Journal of the Centre of Social and Environmental Accounting Research 31 (1): 73-84.

Pesci, C., and E. Costa. 2014. "Content Analysis of Social and Environmental Reports of Italian Cooperative Banks: Methodological Issues." Social and Environmental Accountability Journal 34 (3): 157-171.

Riccaboni, A., and E. L. Leone. 2010. "Implementing Strategies through Management Control Systems: The Case of Sustainability." International Journal of Productivity and Performance Management 59 (2): 130-144.

Robertson, D., and N. Nicholson. 1996. "Expressions of Corporate Responsibility in UK Firms." Journal of Business Ethics 15 (10): 1095-1106. 
Sirimarco, G. 2007. "Soluzioni operative: novità nella relazione sulla gestione al bilancio consolidato." Diritto e Pratica delle Società - II Sole 24 Ore 24: 45-50.

Toms, J. S. 2002. "Firm Resources, Quality Signals and The Determinants of Corporate Environmental Reputation: Some UK Evidence." The British Accounting Review 34: 257-282.

Unerman, J. 2000. "Reflections on Quantification in Corporate Social Reporting Content Analysis." Accounting, Auditing \& Accountability Journal 13 (5): 667-680.

Zeghal, D., and S. A. Ahmed. 1990. "Comparison of Social Responsibility Information Disclosure Media Used by Canadian Firms." Accounting, Auditing \& Accountability Journal 3 (1): 38-53.

\section{Appendix}

Table A1. The area of disclosure for environment

\begin{tabular}{|c|c|c|}
\hline ID & Area & Description \\
\hline 1 & Materials & see $G R I-G 3$ \\
\hline 2 & Energy & see GRI - G3 \\
\hline 3 & Water & see $G R I-G 3$ \\
\hline 4 & Biodiversity & see $G R I-G 3$ \\
\hline 5 & Emissions, effluents and waste & see $G R I-G 3$ \\
\hline 6 & Products and services & see $G R I-G 3$ \\
\hline 7 & Transport & see $G R I-G 3$ \\
\hline 8 & Overall & see GRI - G3 \\
\hline 9 & Quality and certifications & $\begin{array}{l}\text { It refers to information regarding environmental } \\
\text { certificates or quality assurance }\end{array}$ \\
\hline 10 & $\begin{array}{l}\text { General aspects related to the sector of activity (Please notel } \\
\text { that category n. } 10 \text { of environmental aspects refers to all } \\
\text { the information about the environment that does not } \\
\text { directly or indirectly deal with the environmental impact } \\
\text { of the companies' activities but simply DESCRIBES } \\
\text { environmental activities) }\end{array}$ & $\begin{array}{l}\text { elt refers to information that does not measure the impact } \\
\text { Il of activities on the environment, but simply describes } \\
\text { some activities }\end{array}$ \\
\hline 11 & Other & Residual aspects \\
\hline
\end{tabular}

Table A2. The area of disclosure for human resources

\begin{tabular}{|c|c|c|}
\hline ID & Area & Description \\
\hline 1 & Employment & see $\mathrm{GRI}-\mathrm{G} 3$ \\
\hline 2 & $\begin{array}{l}\text { Labour/management } \\
\text { relations }\end{array}$ & see GRI - G3 \\
\hline 3 & $\begin{array}{l}\text { Occupational health and } \\
\text { safety }\end{array}$ & see GRI - G3 \\
\hline 4 & Training and education & see GRI - G3 \\
\hline 5 & $\begin{array}{l}\text { Diversity and equal } \\
\text { opportunity }\end{array}$ & see GRI - G3 \\
\hline 6 & Development policies & $\begin{array}{l}\text { It refers to policies and initiatives devoted to promoting the advancement of careers in } \\
\text { the company }\end{array}$ \\
\hline 7 & Social initiatives & $\begin{array}{l}\text { It refers to initiatives that deal with sports, activities, heath projects and family activities } \\
\text { for the employee }\end{array}$ \\
\hline 8 & Communication & It refers to all forms of internal communication developed in favour of the employee. \\
\hline 9 & Company climate & It refers to employee satisfaction about the climate of the company \\
\hline 10 & Question of law & It refers to legal controversies between the company and the employees \\
\hline 11 & Other & Residual aspects \\
\hline
\end{tabular}

